Gut, 1973, 14, 191-195

\title{
Nyctohemeral growth hormone levels in children with growth retardation and inflammatory bowel disease ${ }^{1,2}$
}

\author{
RONALD W. GOTLIN AND REUBEN S. DUBOIS \\ From the Department of Pediatrics, University of Colorado Medical Center, Denver, Colorado, USA
}

SUMMARY Short stature is a common complication of inflammatory bowel disease. Recently McCaffery, Nasr, Lawrence, and Kirsner (1970) concluded, from blood growth hormone (GH) levels obtained during insulin-hypoglycaemic provocation, that GH deficiency contributed to the retardation in growth observed in subjects with inflammatory bowel disease. Although it was not possible to eliminate the possibility of partial hypopituitarism, this study does not confirm the existence of GH deficiency in six subjects with short stature complicating inflammatory bowel disease. The nyctohemeral (night and day) serum GH is described, and the insulin and glucose levels in these subjects and normal sleep-related GH rises in all are demonstrated. This finding is not compatible with growth hormone deficiency. In one subject the response to arginine provocation was blunted. Three subjects manifested hyperinsulinism and evidence for 'insulin resistance'. These findings are unexplained but suggest that insulin resistance may contribute to a blunted $\mathrm{GH}$ response to insulin-induced hypoglycaemia. Blunted GH response to both arginine and insulin-induced hypoglycaemia may also result from continuous secretion and reduced pituitary storage of growth hormone. This possibility is suggested by the pattern of raised blood $\mathrm{GH}$ levels in one of the subjects.

Retarded growth is a common clinical feature observed in children with inflammatory bowel disease. The pathogenic mechanisms contributing to the failure of growth in these subjects has not been elucidated but it is probably not secondary to endocrine deficiency (Sobel, 1969). Possible causes include caloric deficiency resulting from anorexia or malabsorption and 'end-organ subresponsiveness' in peripheral tissues to adequate serum levels of growth-promoting hormones. Recently McCaffery and his colleagues reported diminished blood growth hormone $(\mathrm{GH})$ levels in 11 children with inflammatory bowel disease and suggested that an endocrine deficiency state resulting from hypopituitarism might be the cause of their short stature (McCaffery et al, 1970). This conclusion was based on subnormal rises in growth hormone observed in response to a conventional growth hormone provocation test, viz, insulin hypoglycaemia.

\footnotetext{
${ }^{1}$ This paper was presented in part at the Western Society for Pediatric Research Meeting on 30 January 1971, at Carmel, California

"Supported by grants from the Human Growth Foundation and the General Clinical Research Centers Program of the Division of Research Resources, National Institutes of Health (RR69).

Received for publication 16 November 1972.
}

The recognition that growth hormone rises physiologically during normal sleep (Takahashi, Kipnis, and Daughaday, 1968) to levels comparable in magnitude and longer in duration than rises observed with conventional provocation tests (Parker, Sassin, Mace, Gotlin, and Rossman, 1969) has made possible a more definitive test of growth hormone secretion (Mace, Gotlin, Sassin, Parker, and Rossman, 1970; Mace, Gotlin, and Beck, 1972). Since marked discrepancies between physiological sleep-related rises of growth hormone and those observed with conventional provocation have been reported (Gotlin, Mace, Sassin, Rossman, and Parker, 1969), we evaluated further the possibility raised by McCaffery and his coworkers that the retarded growth observed in children with inflammatory bowel disease is the result of growth hormone deficiency. The nyctohemeral (night and day) blood levels of growth hormone, insulin, and glucose were studied in six subjects with inflammatory bowel disease and severe growth retardation. In addition the growth hormone levels in response to arginine provocation were compared with rises occurring during natural sleep. The results reported here failed to support the conclusion that a growth hormone deficiency state 
exists in these subjects with inflammatory bowel disease.

\section{Materials and Methods}

Six patients whose ages ranged from 12 years 3 months to 14 years 9 months were studied (table I). Three had chronic ulcerative colitis and a similar number regional enteritis. The diagnosis was made on clinical, sigmoidoscopic, and radiological grounds. Histological confirmation was obtained in four patients. All subjects were below the third percentile for height. Growth data were available in each case and indicated a growth velocity of less than one inch per year for at least three years before our study. All three males had either sexual immaturity or a delay or interruption in the progression of puberty. Two of the three females had delayed onset of menstrual periods and one of these two (case 2) had regression of secondary sexual characteristics after sexual development. Other extraintestinal manifestations included one case each of arthritis (case 5), pericholangitis (case 3), and haemophilia A (case 4).

One subject (case 1) was receiving prednisone ( $5 \mathrm{mg}$ bid) at the time of the study, another (case 4) had been treated intermittently with corticosteroids until two and a half years before our study.

All subjects were admitted to the Clinical Research Center, University of Colorado School of Medicine, for 48 to 72 hours. During this time they were permitted their regular diet and hospital activity.

Blood samples were drawn at hourly intervals over an 18-24-hour period from paediatric scalp vein needles placed in peripheral veins and maintained patent with heparinized saline $(10 \mathrm{U} / \mathrm{ml})$. On the morning after the study night, growth hormone released in response to arginine provocation was determined employing $0.5 \mathrm{~g}$ of arginine (R-gene,
Cutter Laboratories) infused over a 30-minute interval; samples were obtained thereafter at 30,60, 90, and 120 minutes. All specimens were separated immediately by centrifugation and frozen for later analysis of glucose, growth hormone, and insulin.

Serum samples for determination of cortisols was obtained at 0800 and 2200 hours. A 24-hour urine was collected for determination of pituitary gonadotrophins, 17-ketosteroids, and 17-ketogenic steroids. Estimates of thyroid function were obtained by T4 determinations.

The growth hormone and insulin determinations were performed by double antibody radioimmunoassay, growth hormone by the method of Schlach and Parker (1964), insulin by the method of Morgan and Lazarow (1963). Glucose was determined by the glucose oxidase method (Marks, 1959), cortisol by the fluorescent method of Clark and Rubin (1969), T4 by column chromatography (Pileggi and Kessler, 1968), 17-ketosteroids by the method of Norymberski (Sobel, Golub, Henry, Jacobs, and Basu, 1958), 17ketogenic steroids by the Zimmerman reaction (Birke, Diczfalusy, and Plaitin, 1958), and pituitary gonadotrophins by bioassay (Bioscience Laboratories, California).

\section{Results}

\section{GROWTH HORMONE ANALYSIS}

In table I nyctohemeral levels of growth hormone in the six subjects with gastrointestinal disease are compared with results in 30 normal control children of both sexes in the same age range and stage of pubescent development, studied under similar conditions. This table also compares the diurnal and nocturnal means and ranges of $\mathrm{GH}$ levels as well as the maximum observed rise in each subject after arginine infusion. As shown, the six subjects with inflammatory bowel disease all had normal sleep-

\begin{tabular}{|c|c|c|c|c|c|c|c|c|c|}
\hline \multirow{3}{*}{$\begin{array}{l}\text { Subject } \\
\text { Number }\end{array}$} & \multirow[t]{3}{*}{ Age $(y r)$} & \multirow[t]{3}{*}{$\operatorname{Sex}$} & \multirow[t]{3}{*}{ Diagnosis } & \multicolumn{4}{|c|}{ Nyctohemeral Levels } & \multicolumn{2}{|c|}{ Response to Arginine Provocation } \\
\hline & & & & \multicolumn{2}{|c|}{ Diurnal } & \multicolumn{2}{|c|}{ Nocturnal } & \multirow[t]{2}{*}{ Baseline } & \multirow[t]{2}{*}{ Maximum Rise } \\
\hline & & & & Mean & Range & Mean & Range & & \\
\hline \multirow[t]{2}{*}{$\begin{array}{l}1 \\
2 \\
3 \\
4 \\
5 \\
6\end{array}$} & $\begin{array}{l}14-7 / 12 \\
13-7 / 12 \\
13-11 / 12 \\
13-8 / 12 \\
14-9 / 12 \\
12-3 / 12\end{array}$ & $\begin{array}{l}\mathbf{F} \\
\mathbf{F} \\
\mathbf{F} \\
\mathbf{M} \\
\mathbf{M} \\
\mathbf{M}\end{array}$ & $\begin{array}{l}\text { Regional enteritis } \\
\text { Regional enteritis } \\
\text { Ulcerative colitis } \\
\text { Ulcerative colitis } \\
\text { Regional enteritis } \\
\text { Ulcerative colitis }\end{array}$ & $\begin{array}{r}5 \\
9 \\
5 \\
9 \\
7 \\
11\end{array}$ & $\begin{array}{l}2-7 \\
5-12 \\
3-8 \\
8-10 \\
6-7 \\
5-17\end{array}$ & $\begin{array}{r}6 \\
8 \\
5 \\
10 \\
7 \\
8\end{array}$ & $\begin{array}{l}3-13 \\
4-12 \\
2-8 \\
7-15 \\
4-16 \\
6-13\end{array}$ & $\begin{array}{c}5 \\
10 \\
3 \\
8 \\
+2 \\
7\end{array}$ & $\begin{array}{l}23 \\
14 \\
10 \\
11 \\
+2 \\
9\end{array}$ \\
\hline & \multicolumn{3}{|c|}{$\begin{array}{l}\text { Group mean and standard deviation } \\
\text { Control mean and standard deviation } \\
\text { (mean values in parenthesis) }\end{array}$} & \multicolumn{2}{|c|}{$\begin{array}{l}7 \cdot 7 \pm 2 \cdot 4 \\
4 \cdot 2 \pm 1 \cdot 9(1-11)\end{array}$} & $\begin{array}{l}7 \cdot 3 \pm 1 \cdot 7 \\
8 \cdot 1 \pm 2 \cdot 1\end{array}$ & $(11-26)$ & $\begin{array}{l}6 \cdot 6 \pm 2 \cdot 7 \\
2 \cdot 7 \pm 1 \cdot 0\end{array}$ & $\begin{array}{l}13 \cdot 4 \pm 5 \cdot 7 \\
11 \cdot 4 \pm 4 \cdot 2 \\
(9 \cdot 6-18)\end{array}$ \\
\hline
\end{tabular}

Table I Growth hormone levels in normal subjects and subjects with inflammatory bowel disease

${ }^{1}$ Receiving prednisone $5 \mathrm{mg}$ bid at time of study

$2+1=$ Not done 
related GH rises ( $>7 \mathrm{ng} / \mathrm{ml}$ ) (Mace et al, 1970, 1972). Although the range and mean GH levels for the entire nyctohemeral period were slightly elevated in subject 4 , the difference was not statistically significant from controls. The GH response to arginine infusion in control subjects and subjects with gastrointestinal disease was comparable $(>9 \mathrm{ng} / \mathrm{ml}$ taken as the lowest acceptable GH rise in normal subjects) although in subject 6 the baseline level is raised and the response to arginine is blunted.

\section{NYCTOHEMERAL INSULIN AND GLUCOSE}

\section{LEVELS}

The pattern of blood insulins (Table II) showed appropriate rises in response to meals and arginine in all subjects and remained low $(<20 \mathrm{mU} / \mathrm{ml})$ throughout the nocturnal period in all subjects except cases 3 and 4 . (In subject 5, sporadic hyperinsulinaemia in relation to meals was observed.) In these subjects elevated nocturnal levels were observed and were abnormal when compared with the normal controls $(P<0.05)$. The subject receiving prednisone did not have raised nocturnal insulin levels.

The glucose levels in all subjects were normal and varied appropriately with meals. Hypoglycaemia did not occur in the subjects with elevated insulin levels but the insulin: glucose ratios were abnormally elevated.

THYROID, GONAD, AND ADRENAL FUNCTION T4 determinations and 24-hour urinary gonadotrophin and steroid levels were in the normal range in all subjects. With the exception of case 1 , a normal diurnal variation in cortisol was observed. Therefore, although specific or indirect tests of the pituitary-thyroid, pituitary-gonad, and pituitary- adrenal axes were not performed, there was no laboratory evidence of secondary thyroid, gonadal, or adrenal insufficiency.

\section{Discussion and Conclusions}

We have investigated in six subjects with inflammatory bowel disease and severe growth retardation the possibility that deficiency of growth hormone contributes to the retardation in growth frequently observed in these diseases. The results of this study are not in keeping with GH deficiency. Moreover, we did not detect evidence for pituitary-thyroid, pituitary-gonad, or pituitary-adrenal insufficiency.

In a recent report by McCaffery and colleagues it was suggested that the growth retardation commonly associated with inflammatory bowel disease was secondary to hypopituitarism (McCaffery et al, 1970). We have no explanation for the disparity between our results and those reported by McCaffery and associates. Since different methods were employed in assessing growth hormone secretion, the two studies are not entirely comparable.

The blood growth hormone rise observed during natural sleep is a physiological phenomenon which may be altered if deep sleep is delayed or interrupted (Sassin, Parker, Mace, Gotlin, Johnson, and Rossman, 1969). In patients with inflammatory bowel disease, we anticipated that sleep might be disturbed by abdominal discomfort as well as anxiety. In subject 2 of this study, abdominal pain was present throughout the study night interfering with both the onset and continuity of sleep. It is of interest that the blood GH pattern during this period did not show a GH rise until early morning (0400 hours). In normal subjects, sleep-related GH rises usually occur in association with slow wave or deep sleep during the

\begin{tabular}{|c|c|c|c|c|c|c|c|c|c|c|c|c|}
\hline \multirow[t]{3}{*}{$\begin{array}{l}\text { Subject } \\
\text { Number }\end{array}$} & $\frac{\text { Nyctohem }}{\text { Diurnal }}$ & \multicolumn{2}{|c|}{ Nyctohemeral Levels } & & & & Nocturnal & & \multicolumn{4}{|c|}{ Response to Arginine Provocation } \\
\hline & \multicolumn{2}{|l|}{ Mean } & \multicolumn{2}{|l|}{ Range } & \multicolumn{2}{|l|}{ Mean } & \multicolumn{2}{|l|}{ Range } & \multicolumn{2}{|l|}{ Baseline } & \multicolumn{2}{|c|}{ Maximum Rise } \\
\hline & $\begin{array}{l}\text { Insulin } \\
(m U / m l)\end{array}$ & $\begin{array}{l}\text { Glucose } \\
\text { (mg\%) }\end{array}$ & $\begin{array}{l}\text { Insulin } \\
(\mathrm{mU} / \mathrm{ml}\end{array}$ & $\begin{array}{l}\text { Glucose } \\
\text { (mg \%) }\end{array}$ & $\begin{array}{l}\text { Insulin } \\
(m U / m l)\end{array}$ & $\begin{array}{l}\text { Glucose } \\
(m g \%)\end{array}$ & $\begin{array}{l}\text { Insulin } \\
(m U / m l)\end{array}$ & $\begin{array}{l}\text { Glucose } \\
\text { (mg\%) }\end{array}$ & $\begin{array}{l}\text { Insulin } \\
(m U / m l)\end{array}$ & $\begin{array}{l}\text { Glucose } \\
(m g \%)\end{array}$ & $\underset{(m U / m l)}{\text { Insulin }}$ & $\begin{array}{l}\text { Glucose } \\
(m g \%)\end{array}$ \\
\hline $\begin{array}{l}1 \\
2 \\
3 \\
4 \\
5 \\
6\end{array}$ & $\begin{array}{r}9 \\
6 \\
46 \\
53 \\
55 \\
22\end{array}$ & $\begin{array}{r}103 \\
92 \\
100 \\
112 \\
107 \\
94\end{array}$ & $\begin{array}{r}5-15 \\
0-13 \\
43-52 \\
44-57 \\
5-185 \\
17-27\end{array}$ & $\begin{array}{l}83-134 \\
85-103 \\
92-118 \\
87-152 \\
79-163 \\
80-108\end{array}$ & $\begin{array}{r}7 \\
4 \\
43 \\
64 \\
16 \\
22 \\
\end{array}$ & $\begin{array}{r}96 \\
82 \\
100 \\
110 \\
89 \\
101\end{array}$ & $\begin{array}{c}2-18 \\
0-8 \\
30-56 \\
40-138 \\
5-74 \\
5-57\end{array}$ & $\begin{array}{l}74-115 \\
73-94 \\
96-105 \\
93-143 \\
75-122 \\
82-127\end{array}$ & $\begin{array}{r}5 \\
5 \\
45 \\
57 \\
1 \\
7\end{array}$ & $\begin{array}{l}83 \\
88 \\
95 \\
96 \\
1 \\
90\end{array}$ & $\begin{array}{l}28 \\
13 \\
54 \\
68 \\
1 \\
48\end{array}$ & $\begin{array}{r}115 \\
125 \\
113 \\
98 \\
1 \\
91\end{array}$ \\
\hline $\begin{array}{l}\text { Group } \\
\text { Control }\end{array}$ & $\begin{array}{l}\text { mean and } \\
31 \cdot 8 \pm 22 \\
1 \text { mean, sta } \\
27.0 \pm 17\end{array}$ & $\begin{array}{l}\text { andard de } \\
101 \cdot 3 \pm \\
\text { lard devia } \\
98 \cdot 0 \pm 1\end{array}$ & $\begin{array}{l}\text { ion } \\
\text {, and } r \\
5-108\end{array}$ & $\begin{array}{l}\text { inge } \\
56-148\end{array}$ & $\begin{array}{l}26.0 \pm 23 \\
18.0 \pm 26\end{array}$ & $\begin{array}{l}96 \cdot 3 \pm 9 \cdot 8 \\
89 \cdot 0 \pm 4 \cdot 1\end{array}$ & $5-37$ & $79-102$ & $\begin{array}{r}23.8 \pm 25.2 \\
26.0 \pm 8.6\end{array}$ & $\begin{array}{l}90 \cdot 4 \pm \\
84 \cdot 0 \pm\end{array}$ & $\begin{array}{l}42 \cdot 2 \pm 21 \\
74 \cdot 0 \pm 12\end{array}$ & $\begin{array}{l}108 \cdot 4 \pm 13 \cdot 7 \\
106 \cdot 0 \pm 9 \cdot 2\end{array}$ \\
\hline
\end{tabular}

Table II Insulin and glucose levels in normal subjects and subjects with inflammatory bowel disease 
first two hours of natural sleep (Takahashi et al, 1968; Parker et al, 1969).

We have previously observed discrepancies in the same subjects between blood GH rises occurring during sleep and rises observed in response to conventional growth hormone-provoking agents (Gotlin et al, 1969). The absence of blood GH rise in response to insulin hypoglycaemia observed by McCaffery and coworkers is therefore not diagnostic of GH deficiency.

Two additional observations of this study deserve comment. Subject 4 manifested nyctohemeral elevations in blood growth hormone. This is a finding previously observed in subjects with acromegaly (Gotlin et al, 1969), anorexia nervosa (unpublished observation), primordial short stature (Gotlin, Mace, and Silver, 1971), and subjects with other types of gastroenteropathy (Gotlin and Dubois, 1971). Raised nyctohemeral blood GH levels suggest that the hormone is biologically inactive or that the peripheral tissue ('end-organ') is subresponsive. The latter seems more likely and may result from caloric deficiency or other alterations in the internal environment in chronic diseases such as inflammatory bowel disease or chronic renal disease (Simmons, Wilson, Potter, and Holliday, 1971).

Previous reports of elevated 'basal' GH levels and diminished responsiveness to arginine and insulinhypoglycaemic provocation, as observed in our sixth subject, have been reported (Frohman, Aceto, and MacGillivray, 1967; Youlton, Kaplan, and Grumbach, 1969). From examination of the data reported by McCaffery and associates, it seems possible that the diminished $\mathrm{GH}$ response to insulin hypoglycaemia in some of their subjects may have resulted from elevated nyctohemeral GH secretion and depleted pituitary GH stores.

In subjects 3, 4, and 5 elevated blood insulin levels were observed throughout the 24-hour study interval. This finding has been observed previously in subjects with acromegaly (Elkeles, Wright, Lowy, and Fraser, 1969) and exogenous obesity (Gotlin, MacReynolds, and Dubois, 1971), and we have observed hyperinsulinism in other subjects with gastrointestinal disease (Gotlin and Dubois, 1971). The absence of hypoglycaemia in association with hyperinsulinism is paradoxical and suggest that these subjects have developed a state of 'insulin resistance'. Insulin resistance may have interfered with the magnitude of hypoglycaemia in the insulin-hypoglycaemic provocation tests conducted by McCaffery and his colleagues. In their study the degree of hypoglycaemia resulting from conventional insulin provocation cannot be determined since preinsulin provocation glucose levels are not reported; it is conceivable that their subjects may have had hyperinsulinism and a degree of 'insulin resistance' which resulted in ineffective growth hormone stimulation by the insulin provocation test.

Puberty was abnormal in onset and progression in each of our subjects and abnormalities of puberty are common in chronic systemic diseases. The combination of short stature, retarded skeletal maturation, and the deficient caloric intake of gastrointestinal disease states may be of importance in explaining the delayed puberty in our subjects as well as in subjects with other types of chronic disease. Since the timing of onset and progression of puberty may well be controlled by a 'critical weight' (Frisch, 1972), it seems likely that the abnormalities of puberty are a feature of the poor nutritional status of our subjects.

The observed abnormalities of puberty could also be the result of partial hypopituitarism as proposed by McCaffery and coworkers (1970). Since urinary pituitary gonadotrophin levels were not abnormal, our data do not support a hypothalamic-pituitary deficiency or abnormality. Nonetheless, the urinary bioassay of gonadotrophin is a crude assessment of hypothalamic pituitary function and our data do not exclude a partial deficiency or a subtle abnormality in the timing, or in the FSH/LH ratio in these patients. Extensive longitudinal studies, such as are described here for $\mathbf{G H}$, employing sensitive radioimmunoassay techniques for FSH and LH, will be helpful in elucidating these possibilities.

\section{References}

Birke, G., Diczfalusy, E., and Plantin, L. O. (1958). Assessment of the functional capacity of the adrenal cortex. I. Establishment of normal values. J. clin. Endocr., 18, 736-754.

Clark, B. R., and Rubin, R. T. (1969). New fluorometric method for the determination of cortisol in serum. Analyt. Biochem., 29, 31-39.

Elkeles, R. S., Wright, A. D., Lowy, C., and Fraser, T. R. (1969). Serum insulin in acromegaly. Lancet, 2, 615-618.

Frisch, R. E. (1972). Weight at menarche: similarity for well-nourished and undernourished girls at differing ages, and evidence for historical constancy. Pediatrics, 50, 445-450.

Frohman, L. A., Aceto, T., Jr., and MacGillivray, M. H. (1967). Studies of growth hormone secretion in children: normal, hypopituitary and constitutionally delayed. J. clin. Endocr., 27, 1409-1417

Gotlin, R. W., and Dubois, R. S. (1971). Growth hormone, insulin, and glucose levels in children with gastrointestinal disease complicated by short stature (Abstr.). Clin. Res., 19, 201.

Gotlin, R. W., Mace, J. W., Sassin, J. F., Rossman, L. G., and Parker, D. C. (1969). Circadian growth hormone (G.H.) levels in endocrine and growth aberrations. In Proceedings of the 79th Annual Meeting of the American Pediatric Society. (Abstr.)

Gotlin, R. W., Mace, J. W., and Silver, H. K. (1971). Raised nyctohemeral (night and day) growth-hormone levels in conditions with primordial short stature. Lancet, 1, 626-627.

Gotlin, R. W., MacReynolds, J. P., and Dubois, R. S. (1971). Influence of fasting and low simple carbohydrate diet on insulin secretion in exogenous obesity. (Abstr.) Clin. Res., 19, 201.

McCaffery, T. D., Nasr, K., Lawrence, A. M., and Kirsner, J. B. (1970). Severe growth retardation in children with inflammatory bowel disease. Pediatrics, 45, 386-393.

Mace, J. W., Gotlin, R. W., and Beck, P. (1972). Sleep-related human growth hormone release: a test of physiologic growth hormone secretion in children. J. clin. Endocr., 34, 339-341. 
Mace, J. W., Gotlin, R. W., Sassin, J. F., Parker, D. C., and Rossman, L. G. (1970). Usefulness of post-sleep human growth hormone release as a test of physiologic growth hormone secretion. J. clin. Endocr., 31, 225-226.

Marks, V. (1959). An improved glucose-oxidase method for determining blood, C.S.F., and urine glucose levels. Clin. chim. Acta, 4, 395-400.

Morgan, C. R., and Lazarow, A. (1963). Immunoassay of insulin: two antibody system. Diabetes, 12, 115-126.

Parker, D. C., Sassin, J. F., Mace, J. W., Gotlin, R. W., and Rossman, L. G. (1969). Human growth hormone release during sleep, electroencephalographic correlation, J. clin. Endocr., 29, 871-874.

Pileggi, V. J., and Kessler, G. (1968). Determination of organic iodine compounds in serum IV. A new nonincineration technic for serum thyroxine. Clin. Chem., 14, 339-347.

Sassin, J. F., Parker, D. C., Mace, J. W., Gotlin, R. W., Johnson, L. C., and Rossman, L. G. (1969). Human growth hormone release: Relation to slow wave sleep walking cycles. Science, 165, 513-515.
Schalch, D. S., and Parker, M. L. (1964). A sensitive double antibody immunoassay for human growth hormone in plasma. Nature (Lond.), 203, 1141-1142.

Simmons, J. M., Wilson, C. J., Potter, D. E., and Holliday, M. A. (1971). Relation of calorie deficiency to growth failure in children on hemodialysis and the growth response to calorie supplementation. New Engl. J. Med., 285, 653-656.

Sobel, E. H. (1969). In Endocrine and Genetic Disease of Childhood, edited by L. I. Gardner. Saunders, Philadelphia and London.

Sobel, C., Golub, O. J., Henry, R. J., Jacobs, S. L., and Basu, G. K. (1958). Study of the Norymberski methods for determination of 17-ketogenic steroids (17-hydroxycorticosteroids) in urine. J. clin. Endocr., 18, 208-221.

Takahashi, Y., Kipnis, D. M., and Daughaday, W. H. (1968). Growth hormone secretion during sleep. J. clin. Invest., 47, 2079-2090.

Youlton, R., Kaplan, S. L., and Grumbach, M. M. (1969). Growth and growth hormone IV. Limitations of the growth hormone response to insulin and arginine and of the immunoreactive insulin response to arginine in the assessment of growth hormone deficiency in children. Pediatrics, 43, 989-1004. 